\title{
Injected Dose
}

National Cancer Institute

\section{Source}

National Cancer Institute. Injected Dose. NCI Thesaurus. Code C94917.

The activity of a tracer injected at the beginning of a scan. 